\title{
The Effect of Nebulized Magnesium Sulphate on the Incidence of Postoperative Sorethroat
}

\author{
T. Padma', Raju B ${ }^{2}$, Raviraj GS ${ }^{2}$ \\ ${ }^{1}$ Associate Professor, Department of Anesthesia, Sri Venkateshwara Medical Collage, Tirupati, Andhra Pradesh, India, ${ }^{2}$ Postgraduate Student, Department \\ of Anesthesia, Sri Venkateshwara Medical Collage, Tirupati, Andhra Pradesh, India.
}

\section{Abstract}

Background: Postoperative sore throat (POST) is a well-recognized complication that remains unresolved in patients undergoing endotracheal intubation for general anaesthesia. The wide variation in these figures is presumably due to different skills and techniques among anesthetists and to differences between patients in the definition of sore throat. The main aim is to study the attenuating effect of Magnesium sulphate nebulization on the incidence of post-operative sore throat. Subjects and Methods: This is a prospective randomized clinical study. A total number of 100 patients of ASA grade $1 \& 2$, in the age group of 18 - 60 years. The study has been carried out at Sri Venkateswara Ram Narayana Ruia Government General Hospital, Sri Venkateswara Medical College, Tirupati, over a period of 12 months. Results: There was no significant difference among the groups in terms of age, gender and weight. Whereas Magnesium sulphate significantly lessens the POST during swallowing at 4 th hour as compared to Normal saline $(\mathrm{p}<0.05)$ and this statement can be attributed to any population. Conclusion: Post-operative sore throat is one of the most common undesirable anesthesia-associated problems in the patients undergoing GA with an endotracheal tube for routine surgical cases for up to $24 \mathrm{~h}$. Magnesium sulphate was significantly reduces the incidence of POST compared to Normal saline, and it is safe, simple and effective in reducing postoperative sore throat.

Keywords: Incidence, Post operative sore throat, Magnesium sulphate.

Corresponding Author: T. Padma, Associate Professor, , Department of Anesthesia, Sri Venkateshwara Medical Collage, Tirupati, Andhra Pradesh, India.

Email: mahi92003@gmail.com

Received: April 2020

Accepted: April 2020

\section{Introduction}

Postoperative sore throat (POST) is a well-recognized complication that remains unresolved in patients undergoing endotracheal intubation for general anaesthesia. After tracheal intubation, the incidence of sore throat varies from $6.6-90 \%$ and after laryngeal mask insertion from $5.8 \%$ to $34 \% .^{[1-4]}$ the wide variation in these figures is presumably due to different skills and techniques among anesthetists and to differences between patients in the definition of sore throat. Avoiding POST symptoms is a major priority for these patients because preventing postoperative complications contributes to patient satisfaction.

POST has been rated by patients as $8^{\text {th }}$ most undesirable outcome in the postoperative period. ${ }^{[5]}$ it increases the duration of hospital stay and delays discharge, especially in day care surgeries. ${ }^{[6]}$ Routine endotracheal intubation for elective surgical procedures and inadvertent trauma to the airway which accounts for POST symptoms. Awareness of the potential factors is responsible for increased frequency of POST and appropriate precautions especially during endotracheal intubation can help to reduce the incidence of POST.
Numerous non-pharmacological and pharmacological measures have been used for attenuating POST. Among the non-pharmacological methods smaller sized endotracheal tubes, careful airway instrumentation, minimising the number of laryngoscopy attempts, intubation after the full relaxation of the larynx, gentle oropharyngeal suctioning, Filling the cuff with an anaesthetic gas mixture, minimizing intracuff pressures $<20 \mathrm{~mm} \mathrm{Hg}$ and extubation when the endotracheal tube is fully deflated, have been reported to decrease the incidence of POST. ${ }^{[3,7]}$

Pharmacological measures for attenuating POST are inhalation of beclomethasone and fluticasone, gargling with azulene sulfonate, ketamine, local spray of benzydamine hydrochloride and intra cuff administration of alkalinized lignocaine. ${ }^{[8,9]}$ The discomfort associated with airway inflammation can possibly be reduced by application of locally active anti-inflammatory and analgesic agents preemptively. In this regard ketamine (phencyclidine derivative) and benzydine hydrochloride (topical NSAID) has been used independently as preoperative gargle and noted to decrease the incidence and severity of POST. ${ }^{[8,9]}$

It is known that n-methyl-d-aspartate (NMDA) has a role in nociception and inflammation. NMDA receptors are found in peripheral nerves and in the central nervous system. Hence 
NMDA antagonists such as ketamine work on peripheral nerve endings in pharyngeal mucosa and can decrease the incidence of sore throat. ${ }^{[8]}$

Magnesium is also an antagonist of the NMDA receptor ion channel. ${ }^{[10]}$ In our study we plan to study the efficacy of magnesium sulphate nebulization to reduce the incidence of POST. The drug being easily available and nebulization may be simple, cost-effective method to decrease POST symptoms.

\section{Subjects and Methods}

This is a prospective randomized clinical study.A total number of 100 patients of ASA grade $1 \& 2$ in the age group of 18 - 60 years of either sex posted for elective surgeryy under general anaesthesia for $>2 \mathrm{hrs}$ duration, they were divided into two groups (A \&B). The Study has been carried out at Sri Venkateswara Ram Narayana Ruia Government General Hospital, Sri Venkateswara Medical College, Tirupati, over a period of 12 months.

Group "A"- Patients in group A are nebulised with $3 \mathrm{ml}$ of normal saline.

Group"B"- Patients in group B are nebulised with $3 \mathrm{ml}$ of $225 \mathrm{mg}$ isotonic nebulised magnesium sulphate for 15 minutes, 5 minutes before induction of anaesthesia.

All patients will be premedicated with tab. Alprazolam $0.5 \mathrm{mg}$ and tab. Ranitidine $150 \mathrm{mg}$ on night before surgery and on morning of surgery. All patients were kept fasting overnight.

Patients in group A were nebulised with $3 \mathrm{ml}$ of normal saline and the patients in group B weree nebulised with $3 \mathrm{ml}$ of $225 \mathrm{mg}$ isotonic nebulised magnesium sulphate for 15 minutes, 5 minutes before induction of anaesthesia.

After taking patient into the operation theatre patient was connected to standard monitors consisting of ECG and pulse oxymeter, non-invasive BP monitor, then IV access was done under strict asepsis before induction.

Anaesthesia was induced with inj:fentanyl $2 \mathrm{mcg} / \mathrm{kg}$ and inj:thiopentone $5 \mathrm{mg} / \mathrm{kg}$. Tracheal intubation was facilitated by Atracurium $0.6 \mathrm{mg} / \mathrm{kg}$,trachea intubated with soft seal cuffed sterile polyvinyl chloride endotracheal tube (Portex Limited CT 21, 6JL, UK) $7 \mathrm{~mm}$ inner diameter for female and $8 \mathrm{~mm}$ for male patients. The tracheal tube cuff was inflated with air.

The cuff pressure was checked after intubation using hand held endotracheal cuff pressure monitor (Portex Cuff Inflator/Pressure Gauge, SIMS Portex, Hythe, Kent, and UK) and then every 30min till end of surgery and pressure maintained at $20 \mathrm{~cm}$ of $\mathrm{H} 2 \mathrm{O}$.

Anaesthesia was maintained with $66 \%$ nitrous oxide in oxygen with $1 \%$ of isoflurane and intermittent doses of atracurium and fentanyl as required. Last dose of atracurium was given 20 minutes prior to extubation. At the end of surgery, the muscle relaxation was reversed with a combination of Neostigmine $0.05 \mathrm{mg} / \mathrm{kg}$ and Glycopyrrolate $0.01 \mathrm{mg} / \mathrm{kg}$. Patients were extubated after meeting regular extubation criteria.Tracheal extubation was done following gentle suctioning of oral secretions by a $14 \mathrm{~F}$ soft suction catheter and patients were shifted to post operative anaesthesia care unit and Incidence of postoperative sore throat at rest and on swallowing and any undue complaints at $0,2,4$ and 24 hours evaluated. In the postoperative ward patients were also monitored for any drug related side effects.

Inclusion criteria:

- ASA grade $1 \& 2$ patients

- Age group of 18 - 60 years

- Patients giving valid informed consent

- Patients undergoing elective surgery of approximately $2 \mathrm{hrs}$ or more duration requiring tracheal intubation.

Exclusion criteria:

- Patient refusal.

- ASA grade 3 or 4

- Age $<18$ or $>60$.

- Neuromuscular disease.

- Allergy or hypersensitivity of drugs.

- Neck surgeries.

- Laparoscopic surgeries.

\section{Results}

There was no significant difference among the groups in the terms of age, gender, weight. Mean age in patients nebulized with normal saline and magnesium sulphate were 46.58 with SD 9.9 and 42.82 with SD 9.1 respectively with total mean of 44.7 with SD 9.65 .

The mean weight in patients nebulized with normal saline and magnesium sulphate were 60.82 with SD 6.703 and 63.44 with SD of 6.478 respectively with total mean of 62.13 with SD 6.68 .

In patients nebulized with normal saline $44 \%$ were female and $56 \%$ were male and in patients nebulized with magnesium sulphate $48 \%$ were female and $52 \%$ were male.

Significant difference between groups was observed in case of Weight. From the Test of Normality, it was concluded that Kolmogrov-Smirnov (.000) / Shapiro-Wilk (.006) p-value is lesser than the threshold value (0.05) at $100 \mathrm{df}$, suggesting significant difference between the observed weight and expected weight of the patient, but not clinically significant.

Table 1: Demographic data presented as either, Mean with $95 \%$ confidence interval for mean or as numbers.

\begin{tabular}{|l|l|l|l|}
\hline Variables & $\begin{array}{l}\text { Normal } \\
\text { Saline }\end{array}$ & $\begin{array}{l}\text { Magnesium } \\
\text { Sulphate }\end{array}$ & P Value \\
\hline Age (yr.) Mean and SD & $46.58 \pm 9.908$ & $42.82 \pm 9.106$ & $\mathrm{p}=0.051$ \\
\hline $\begin{array}{l}\text { Gender (M/F) number } \\
\text { (n) }\end{array}$ & $28 / 22$ & $26 / 24$ & $\mathrm{p}=0.688$ \\
\hline Weight (kg) & $60.82 \pm 6.703$ & $63.44 \pm 6.478$ & $\mathrm{p}=0.050$ \\
\hline
\end{tabular}

From chi-square tests, $\mathrm{P}$ value at $0^{\text {th }}, 2^{\text {nd }}$ and $4^{\text {th }}$ hour is greater than 0.05. From above we can conclude that there was no significant difference in postoperative sore throat at rest during $0^{\text {th }}, 2^{\text {nd }}$ and $4^{\text {th }}$ hour between Normal saline and Magnesium sulphate. Significant difference was seen at $24^{\text {th }}$ hour ( $\mathrm{p}<0.05$ ), where $\mathrm{MgSO}_{4}$ lessens POST, but it was not relied as cell frequency was $<5$.

From the Risk Estimate Table, the Relative Risk (RR) of the patient nebulised with Normal saline is $1.211,1.258$ and 1.714 times more likely to have pain than Magnesium sulphate at $0^{\text {th }}, 2^{\text {nd }}$ and $4^{\text {th }}$ hour at rest. 
Inference: The variation in the data was due to chance error but not due to administration of Normal Saline and Magnesium sulphate at 0,2, 4 hours at rest respectively but at $24^{\text {th }}$ hour, the variation in the data is attributed to clinical groups. This might be due to Zero cell frequency and cannot rely on the inference.

Table 2: Postoperative Sore Throat "At Rest"

\begin{tabular}{|c|c|c|c|c|c|c|}
\hline Time & Nebulized drug & Post & $\begin{array}{l}\text { Pearson Chisquare } \\
\text { P Value }\end{array}$ & $\begin{array}{l}\text { Fisher's Exact } \\
\text { Test }\end{array}$ & Phi & $\begin{array}{l}\text { Relative Risk When } \\
\text { N.S Is Used }\end{array}$ \\
\hline \multirow[t]{2}{*}{$0 \mathrm{HR}$} & N.S $(n=50)$ & $12(24 \%)$ & \multirow[t]{2}{*}{0.461} & \multirow[t]{2}{*}{0.624} & \multirow[t]{2}{*}{-0.074} & \multirow[t]{2}{*}{1.211} \\
\hline & $\mathrm{MgSO}_{4}(\mathrm{n}=50)$ & $9(18 \%)$ & & & & \\
\hline \multirow[t]{2}{*}{$2 \mathrm{HR}$} & N.S $(n=50)$ & $10(20 \%)$ & \multirow[t]{2}{*}{0.424} & \multirow[t]{2}{*}{0.595} & \multirow[t]{2}{*}{-0.080} & \multirow[t]{2}{*}{1.258} \\
\hline & $\mathrm{MgSO}_{4}(\mathrm{n}=50)$ & $7(14 \%)$ & & & & \\
\hline \multirow[t]{2}{*}{$4 \mathrm{HR}$} & N.S $(n=50)$ & $11(22 \%)$ & \multirow[t]{2}{*}{0.102} & \multirow[t]{2}{*}{0.171} & \multirow[t]{2}{*}{-0.164} & \multirow[t]{2}{*}{1.714} \\
\hline & $\mathrm{MgSO}_{4}(\mathrm{n}=50)$ & $5(10 \%)$ & & & & \\
\hline \multirow[t]{2}{*}{$24 \mathrm{HR}$} & N.S $(n=50)$ & $7(14 \%)$ & \multirow[t]{2}{*}{0.006} & \multirow[t]{2}{*}{0.012} & \multirow[t]{2}{*}{-0.274} & \multirow[t]{2}{*}{-} \\
\hline & $\mathrm{MgSO} 4(\mathrm{n}=50)$ & $0(0 \%)$ & & & & \\
\hline
\end{tabular}

Table 3: Postoperative Sore Throat "On Swallowing"

\begin{tabular}{|c|c|c|c|c|c|c|}
\hline Time & $\begin{array}{l}\text { Nebulized } \\
\text { Drug }\end{array}$ & Post $\mathbf{N}=50$ & $\begin{array}{l}\begin{array}{l}\text { Pearson Chisquare } \\
\text { Value }\end{array} \\
\end{array}$ & Fisher's Exact Test & Phi & $\begin{array}{l}\text { Relative Risk When } \\
\text { N.S Is Used } \\
\end{array}$ \\
\hline \multirow[t]{2}{*}{$0 \mathrm{HR}$} & N.S $(n=50)$ & $10(20 \%)$ & \multirow[t]{2}{*}{1.000} & \multirow[t]{2}{*}{0.598} & \multirow[t]{2}{*}{0.000} & \multirow[t]{2}{*}{1.000} \\
\hline & $\mathrm{MgSO}_{4}(\mathrm{n}=50)$ & $10(20 \%)$ & & & & \\
\hline \multirow[t]{2}{*}{$2 \mathrm{HR}$} & N.S $(n=50)$ & $15(30 \%)$ & \multirow[t]{2}{*}{0.286} & \multirow[t]{2}{*}{0.356} & \multirow[t]{2}{*}{-0.115} & \multirow[t]{2}{*}{1.333} \\
\hline & $\mathrm{MgSO}_{4}(\mathrm{n}=50)$ & $10(20 \%)$ & & & & \\
\hline \multirow[t]{2}{*}{$4 \mathrm{HR}$} & N.S $(n=50)$ & $16(32 \%)$ & \multirow[t]{2}{*}{0.027} & \multirow[t]{2}{*}{0.048} & \multirow[t]{2}{*}{-0.221} & \multirow[t]{2}{*}{1.949} \\
\hline & $\mathrm{MgSO}_{4}(\mathrm{n}=50)$ & $7(14 \%)$ & & & & \\
\hline \multirow[t]{2}{*}{$24 \mathrm{HR}$} & N.S $(n=50)$ & $9(18 \%)$ & \multirow[t]{2}{*}{0.025} & \multirow[t]{2}{*}{0.051} & \multirow[t]{2}{*}{-0.224} & \multirow[t]{2}{*}{2.966} \\
\hline & $\mathrm{MgSO}_{4}(\mathrm{n}=50)$ & $2(4 \%)$ & & & & \\
\hline
\end{tabular}

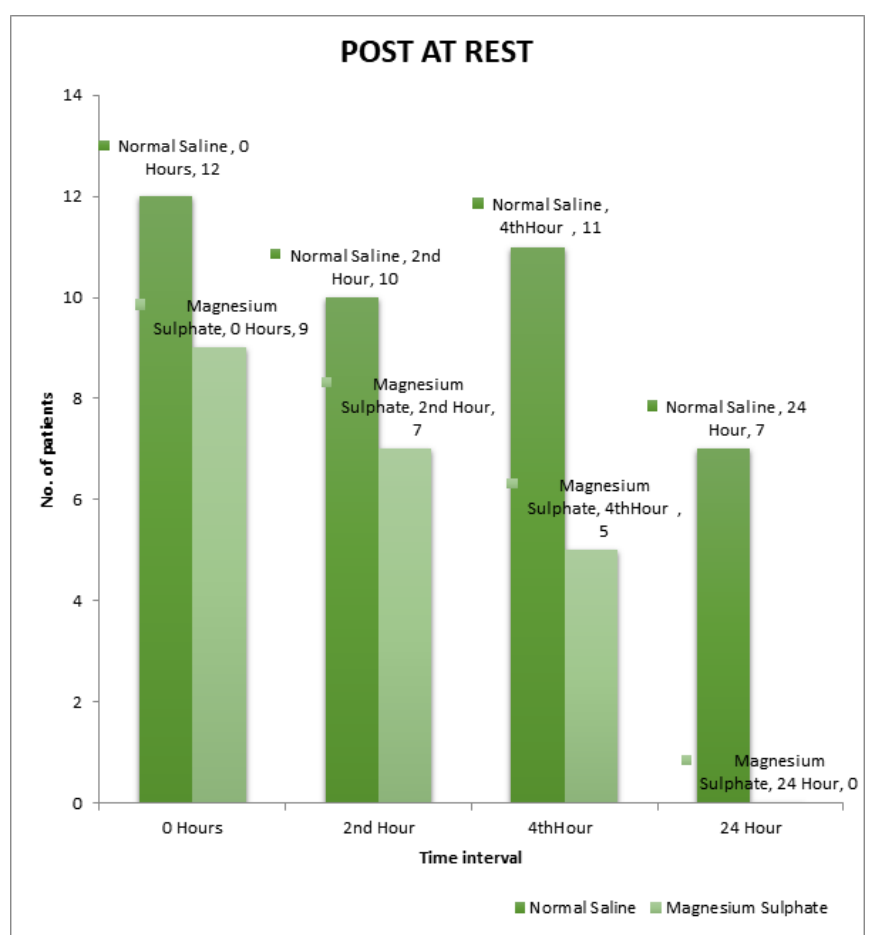

Figure 1: Post Operative Sore Throat At Rest

From chi-square tests, the $\mathrm{P}$ value at $0^{\text {th }}$ and $2^{\text {nd }}$ hour is greater than 0.05 , suggesting no significant difference whereas in postoperative sore throat "on swallowing" during $0^{\text {th }}$ and $2^{\text {nd }}$ hour between Normal saline and Magnesium sulphate.But there was Significant difference seen at $4^{\text {th }}$ hour ( $\mathrm{p}<0.05$ ), where $\mathrm{MgSO}_{4}$ has been shown to lessen postoperative sore throat (POST).

From symmetric measures table, it was confirmed that there was no association between the pain- "on swallowing" and clinical treatments at $0^{\text {th }}, 2^{\text {nd }}, 4^{\text {th }}$ and $24^{\text {th }}$ hour.
From Risk Estimate Table, the Relative Risk (RR) of the patient administered with Normal saline was same, 1.000, 1.333 and 1.949 times more likely to have pain than Magnesium sulphate at $0^{\text {th }}, 2^{\text {nd }}$ and $4^{\text {th }}$ hour- "On Swallowing".

Inference: Significant difference was seen at 4th hours i.e., the difference in percentages for Normal Saline (32\%) and Magnesium sulphate (14\%) was significant i.e., Magnesium sulphate lessens the POST / pain during swallowing at 4 hrs.' - Post operatively as compared to Normal saline and this statement can attribute to any population.

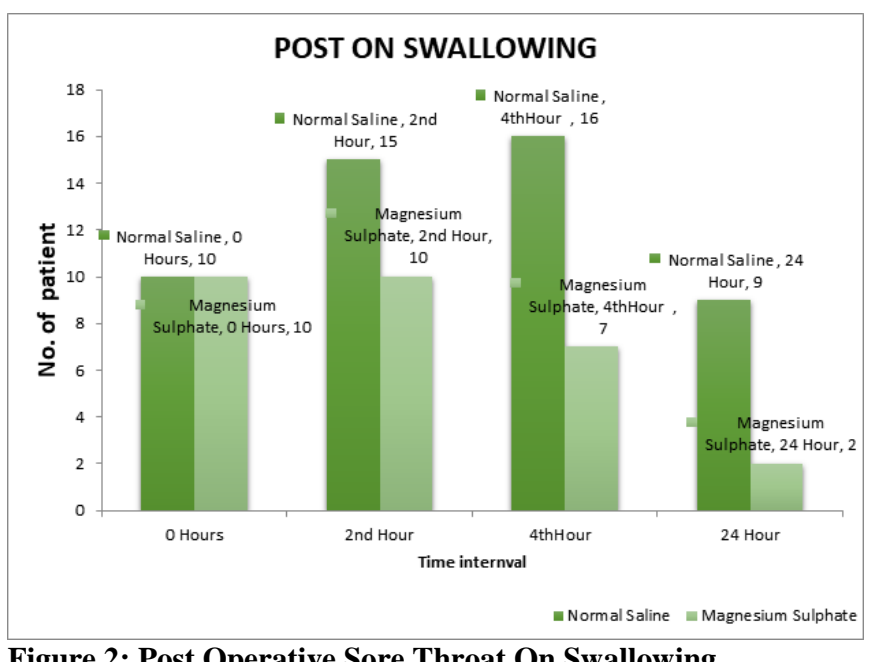

Figure 2: Post Operative Sore Throat On Swallowing

There was no significant difference in postoperative sore throat at rest between Normal saline and Magnesium sulphate ( $p$ >0.05) and also there was no significant difference in postoperative sore throat on swallowing between Normal saline and Magnesium sulphate ( $p>0.05$ ). But age group between 30 to 45 years was shown significant 
difference at 2 hours and 4 hours after extubation ( $\mathrm{p}<0.05)$. There where also increased incidence of POST in patients nebulized with normal saline.

Table 4: Postoperative Sore Throat "At Rest" "Based On Age" Fisher's Exact Test 'P' Value

\begin{tabular}{|l|l|l|l|l|}
\hline Age & $\mathrm{O} \mathrm{Hr}$ & $2 \mathrm{Hr}$ & $4 \mathrm{Hr}$ & $24 \mathrm{Hr}$ \\
\hline$<30$ Years & 1.000 & 0.132 & 0.999 & 0.249 \\
\hline 30-45 Years & 1.000 & 0.931 & 0.061 & 0.233 \\
\hline$>45$ Years & 0.534 & 0.131 & 0.571 & 0.071 \\
\hline
\end{tabular}

Table 5: Postoperative Sore Throat "On Swallowing"

\section{Fisher's Exact Test ' $P$ ' Value}

\begin{tabular}{|l|l|l|l|l|}
\hline Age & $\mathrm{O} \mathrm{Hr}$ & $2 \mathrm{Hr}$ & $4 \mathrm{Hr}$ & $24 \mathrm{Hr}$ \\
\hline$<30$ Years & 0.461 & 0.113 & 1.000 & 0.173 \\
\hline 30-45 Years & 1.000 & 0.022 & 0.013 & 0.234 \\
\hline$>$ 45 Years & 1.000 & 0.394 & 0.611 & 0.233 \\
\hline
\end{tabular}

Inference: With respect to age, there was no significant difference in postoperative sore throat at rest and on swallowing between Normal saline and Magnesium sulphate. But there was significant difference in age group 30 to 45 years. There where also increased incidence of POST in patients nebulised with normal saline.

Table 6: postoperative sore throat based on "weight" "at rest" Fisher's Exact Test 'P Value'

\begin{tabular}{|l|l|l|l|l|}
\hline Weight & $0 \mathrm{HR}$ & $2 \mathrm{HR}$ & $4 \mathrm{HR}$ & $24 \mathrm{HR}$ \\
\hline$<60 \mathrm{Kgs}$ & 0.071 & 0.098 & 0.898 & 0.332 \\
\hline$>60 \mathrm{Kgs}$ & 0.109 & 0.001 & 0.021 & 0.401 \\
\hline
\end{tabular}

Table 7: postoperative sore throat based on "weight""on swallowing"

Fisher's Exact Test 'P Value'

\begin{tabular}{|l|l|l|l|l|}
\hline Weight & $0 \mathrm{HR}$ & $2 \mathrm{HR}$ & $4 \mathrm{HR}$ & $24 \mathrm{HR}$ \\
\hline$<60 \mathrm{Kgs}$ & 0.249 & 0.436 & 0.244 & 0.372 \\
\hline$>60 \mathrm{Kgs}$ & 0.540 & 0.623 & 0.004 & 0.033 \\
\hline
\end{tabular}

There was no significant difference in postoperative sore throat "at rest" and "on swallowing" with respect to weight categories between Normal saline and Magnesium sulphate ( $\mathrm{p}>0.05)$.

But weight categories more than $60 \mathrm{kgs}$ at 2 hours and 4 hours "at rest" and "on swallowing" at 4 hours and 24 hours ( $p<0.05$ ), shown the incidence of sore throat higher in patients nebulized with Normal saline as compared to Magnesium sulphate.

Table 8: postoperative sore throat "based on gender" "at rest" Fisher's exact test " $p$ " value

\begin{tabular}{|l|l|l|l|l|}
\hline Sex & O HR & 2 HR & 4 HR & $24 \mathrm{HR}$ \\
\hline Female & 0.624 & 0.292 & 0.420 & 0.700 \\
\hline Male & 0.482 & 0.792 & 0.543 & 0.343 \\
\hline
\end{tabular}

Table 9: post "based on gender" "on swallowing"

\begin{tabular}{|l|l|l|l|l|}
\hline \multicolumn{5}{|l|}{ Fisher's exact test “p” value } \\
\hline Sex & O HR & 2 HR & 4 HR & $24 \mathrm{HR}$ \\
\hline Female & 0.491 & 0.550 & 0.372 & 0.556 \\
\hline Male & 0.369 & 0.535 & 0.806 & 0.315 \\
\hline
\end{tabular}

From chi-square tests, it was concluded that Fisher's Exact test p-value is greater than the threshold value (Level of significance $=0.05)$. Gender has no significant difference in postoperative sore throat "AT REST" and "ON SWALLOWING" between normal saline and magnesium sulphate.

Table 10: postoperative sore throat based on "smoking" "at rest.

Fisher's exact test 'p value'

\begin{tabular}{|l|l|l|l|l|}
\hline Smoking & $0 \mathrm{HR}$ & $2 \mathrm{HR}$ & $4 \mathrm{HR}$ & $24 \mathrm{HR}$ \\
\hline Yes & 0.655 & 0.742 & 0.699 & 0.454 \\
\hline No & 0.293 & 0.616 & 0.487 & 1.000 \\
\hline
\end{tabular}

Table 11: post based on "smoking" "on swallowing"

Fisher's exact test ' $p$ value'

\begin{tabular}{|l|l|l|l|l|}
\hline Smoking & $0 \mathrm{HR}$ & $2 \mathrm{HR}$ & $4 \mathrm{HR}$ & $24 \mathrm{HR}$ \\
\hline Yes & 0.742 & 0.524 & 0.524 & 0.354 \\
\hline No & 0.344 & 0.344 & 0.556 & 0.772 \\
\hline
\end{tabular}

From chi-square tests, it can be concluded that Fisher's Exact test p-value is greater than the threshold value (Level of significance $=0.05)$. History of smoking has shown no significant difference in postoperative sore throat "AT REST" and "ON SWALLOWING" between Normal saline and Magnesium sulphate.

\section{Discussion}

This study was designed to compare the effect of preoperative nebulization of Normal saline versus Magnesium sulphate in reducing the incidence of postoperative sore throat (POST) following general anaesthesia with endotracheal tube for elective surgeries for $>2 \mathrm{hrs}$.' duration. Total 100 patients with ASA grade $1 \& 2$ in the age group of 18 - 60 years of either sex included.

POST is considered as one of the most common undesirable anesthesia-associated problems. $^{[1]}$ POST can be multifactorial in origin, including mechanical injury during laryngoscopy and intubation, continuous pressure by the inflated tracheal tube cuff on tracheal mucosa causing damage and dehydration of the mucosa.

In this study, in control group, the incidence of POST at rest at $0 \mathrm{hr} ., 2$ hours, 4 hours and 24 hour after extubation were $24 \%, 22 \%, 20 \%$ and $14 \%$ respectively i.e. the average incidence was $14-24 \%$ at rest and the incidence of POST on swallowing at 0 hour, 2 hours, 4 hours and 24 hours weree $20 \%, 30 \%, 32 \%$ and $18 \%$ respectively i.e. the average incidence on swallowing was 18-32\% and highest at 4 hours after extubation.

In this study there was no significant difference was found between the study groups in terms of age, gender, weight and smoking history. Several contributing factors for POST has been attributed, including patient gender, age, type of surgery (gynecological surgery), use of succinyl choline, duration of anaesthesia, larger tracheal tubes, cuff design, and intracuff pressures. ${ }^{[3,6]}$

Biro et al, ${ }^{[11]}$ prospectively followed up 809 adult patients who underwent elective surgical interventions and examined their history, the applied anaesthetic techniques, perioperative course and the occurrence, intensity and duration of postoperative throat complaints. Postoperative sore throat was present in $40 \%$ overall being significantly higher in female than in male (44\% vs. $33 \%$; $\mathrm{P}=0.001)$.

Chen et al, ${ }^{[12]}$ also noted more incidence of post-operative sore throat (POST) in female patients.

Jaensson et al, ${ }^{[13]}$ studied to determine gender differences in 
the incidence of POST after laryngeal mask airway (LMA) and endotracheal tube (ETT). The incidence of sore throat was higher postoperatively after an ETT than an LMA (32\% vs. $19 \%, p=0.012)$. Significantly more women than men had POST after an LMA (26\% vs. $6 \%, \mathrm{p}=0.004)$. No significant gender difference was found in POST after an ETT (27\% vs. $38 \%, p>0.05)$. Similar results were observed in our study does not show any gender difference (20\% vs. $12 \%, \mathrm{p}>0.05)$.

Table 12: Comparison of Gender differences in the incidence of POST after endotracheal tube (ETT) in various studies.

\begin{tabular}{|l|l|l|l|}
\hline Study & $\begin{array}{l}\text { Male } \\
(\% \text { of POST })\end{array}$ & $\begin{array}{l}\text { Female } \\
(\% \text { of POST) }\end{array}$ & Significance \\
\hline $\begin{array}{l}\text { Ahmed et al } \\
(2007))^{[14]}\end{array}$ & $19 \%$ & $27 \%$ & $\mathrm{~F}>\mathrm{M}(\mathrm{p}<0.05)$ \\
\hline${\text { Higgins et al }{ }^{[6]}}^{[1]}$ & $9.1 \%$ & $13.4 \%$ & $\mathrm{~F}>\mathrm{M}(\mathrm{p}<0.05)$ \\
\hline Biro et al, ${ }^{[11]}$ & $33 \%$ & $44 \%$ & $\mathrm{~F}>\mathrm{M}(\mathrm{p}<0.05)$ \\
\hline${\text { Jaensson et al, }{ }^{[13]}}$ & $27 \%$ & $38 \%$ & $\begin{array}{l}\text { Not significant }(\mathrm{p} \\
>0.05)\end{array}$ \\
\hline Our study & $12 \%$ & $20 \%$ & $\begin{array}{l}\text { Not significant }(\mathrm{p} \\
>0.05)\end{array}$ \\
\hline
\end{tabular}

Chen et al, ${ }^{[12]}$ studied the risk factors of postoperative sore throat in patients undergoing endotracheal general anesthesia and five risk factors associated with postoperative sore throat were identified. They were female gender, age between $30-$ 39 years, surgical sites within the oral or nasal cavity, or around the neck, use of nitrous oxide during anesthesia, and duration of anesthesia longer than 2 hours. They observed higher incidence of POST in age between 30-39 years, similar observation has been observed in our study, where an increased incidence of POST has been observed in the patients aged between 30-45 years in whom POST was seen to be higher at 4 th hour on swallowing.

In relation to factors contributing to development of POST, Ahmed et al (2007), ${ }^{[14]}$ observed $37 \%$ of patients having procedure lasting more than 2 hours complained of POST, whereas $<8 \%$ of patients having procedure lasting less than one hour developed sore throat postoperatively. In this study, patients undergoing elective surgeries of approximately 2 hrs.' or more duration are included. There was no significant difference between the two groups ( $\mathrm{p}>0.05)$.

Higgins et al6 studied 5264 ambulatory surgical patients prospectively to determine the anaesthetic, and surgical factors associated with sore throat. POST was higher in gynaecological procedure and in those where succinylcholine was used. It has been suggested that suxamethonium, which is known to cause postoperative skeletal muscle pain, could also lead to pain in the striated pharyngeal muscles, causing sore throat.

In $\mathrm{MgSO}_{4}$ group, the incidence of POST at rest was $18 \%$ at 0 hr., $14 \%$ at $2 \mathrm{hr}, 10 \%$ at $4 \mathrm{hr}$ and $0 \%$ at $24 \mathrm{hr}$. Magnesium sulphate nebulisation does not show any difference on POST at rest in comparison to Normal Saline at 0 hours, 2 hours, 4 hours. The variation in the data is due to chance error but not due to administration of Normal Saline and Magnesium sulphate. At $24^{\text {th }}$ hour, the variation in the data is attributed to clinical groups. This might be due to Zero cell frequency and can't rely on the inference.

The incidence of POST in $\mathrm{MgSo}_{4}$ group, on swallowing was $20 \%$ at 0 hour, $20 \%$ at 2 hours, $14 \%$ at 4 hours and $4 \%$ at 24 hours. Therefore the incidence of POST on swallowing at 0 hour, 2 hours, 4 hours and 24 hours are 20\%, 30\%, 32\% and $18 \%$ respectively. There is an evidence to say that Magnesium sulphate lessens the pain during swallowing at 4 hours post operation as compared to Normal saline and this statement can be attributed to any population. Borazan et al, ${ }^{[15]}$ found a similar result, with incidence of POST at $4 \mathrm{hr}$. being higher in control group than in magnesium group, with incidences of POST at $0 \mathrm{hr}$. and $24 \mathrm{hr}$. not significant between groups.

The incidence of POST was significantly more frequent in the control group compared to both the study groups at alltime points according to Risk estimate tables. In this study more number of patients suffered from POST in control group when compared to both the study groups.

Sore throat related to orotracheal tube might be a consequence of localized trauma, leading to aseptic inflammation of the pharyngeal mucosa. Magnesium being a NMDA receptor antagonist has a role in preventing NMDA receptor-mediated nociception and inflammation and thereby POST. ${ }^{[16]}$ In a recently published study by Ahuja et al., ${ }^{[17]}$ a similar mechanism of action was proposed for preoperative nebulization of ketamine. Similar to Blitz et al. ${ }^{[18]}$ that used nebulized Magnesium sulphate for treatment of acute asthma, our study did not find any either local or systemic adverse outcomes.

There were no serious adverse effects with use of nebulized magnesium sulphate. ${ }^{[19]}$ In our study no adverse outcomes were noted either local or systemic by using magnesium sulphate in the form of nebulization. Maurice et al, ${ }^{[19]} \mathrm{did}$ not observe any serious adverse events with use of nebulized magnesium sulphate for treatment of acute asthma.

In this study patients who are $>60 \mathrm{kgs}$ had increased incidence of POST at 2hours and 4 hours "at rest" and at 4 hours and 24 hours "on swallowing", when nebulized with normal saline compared to magnesium sulphate.

\section{Limitations:}

There are limitations in this study which need to be noted. The drawback of our study was the absence of the measurements of serum magnesium levels. So it was difficult to rule out the contribution of systemic effects of magnesium in our results. Moreover comparing the doses used in the treatment of pre-eclampsia and eclampsia, the dose used in our study was very low and further it has been used in the form of nebulization, absorption for which, by this route has been shown to be variable and low $(10 \%){ }^{[20]}$ The study dose was relatively low and we were not observe any adverse effects.

\section{Conclusion}

Post-operative sore throat (POST) is one of the most common undesirable anesthesia-associated problems in the patients undergoing GA with an endotracheal tube for routine surgical cases for up to $24 \mathrm{~h}$. Magnesium sulphate was significantly reduces the incidence of POST compared to Normal saline, and it is safe, simple and effective in reducing postoperative sore throat.

\section{References}

1. Sumathi PA, Shenoy T, Ambareesha M, Krishna HM. Controlled 
comparison between betamethasone gel and lidocaine jelly applied over tracheal tube to reduce postoperative sore throat, cough, and hoarseness of voice. Br J Anaesth 2008; 100:215-8.

2. Christensen AM, Willemoes-Larsen H, Lundby L, Jakobsen KB. Postoperative throat complaints after tracheal intubation. Br J Anaesth. 1994;73:786-7.

3. McHardy FE, Chung F: Postoperative sore throat; cause, and treatment. Anaesthesia 1999; 54: 444-53.

4. Dingley J, Whitehead MJ, Wareham K. A comparative study of the incidence of sore throat with the laryngeal mask airway. Anaesthesia 1994; 49: 251-4

5. Macario A, Weinger M, Carney S, Kim which clinical anesthesia outcomes are important to avoid? The perspective of patients. Anesth Analg 1999; 89: 652-8.

6. Higgins PP, Chung F, Mezei G: Postoperative sore throat after ambulatory surgery. Br J Anaesth 2002; 88: 582-4.

7. Ratnaraj J, Todorov A, McHugh T, Cheng MA, Lauryssen C. Effects of decreasing endotracheal tube cuff pressures during neck retraction for anterior cervical spine surgery. J Neurosurg. 2002;97(2 Suppl):176-179. doi:10.3171/spi.2002.97.2.0176.

8. Canbay O, Celebi N, Sahin A, Celiker V, Ozgen S, Aypar U. Ketamine gargle for attenuating postoperative sore throat. Br J Anaesth 2008; 100:490-3.

9. Agarwal A, Nath SS, Goswami D, Gupta D, Dhiraaj S, Singh PK. An evaluation of the efficacy of aspirin and benzamine hydrochloride gargle for attenuating postoperative sore throat: A prospective, randomized, single-blind study. Anesth Analog 2006; 103:1001-3.

10. Ascher P, Nowak L. Electrophysiology studies of NMDA receptors. Trends Neurosci 1987; 10:284-8. http://www.sciencedirect.com/science/article/pii/0166223687901743.

11. Biro P, Seitert B, Pasch T: Complaints of sore throat after tracheal intubation: a prospective evaluation. Eur J Anaesthesiol 2005; 22: $307-$ 11.

12. Chen KT, Tzeng JI, Lu CL, Liu KS, Chen YW, Hsu CS, Wang JJ: Risk factors associated with postoperative sore throat after tracheal intubation: an evaluation in the post anesthetic recovery room, Acta Anaesthesiol Taiwan 2004; 42: 3-8.

13. Jaensson M, Gupta A, Nilsson U et al. Gender differences in sore throat and hoarseness following endotracheal tube or laryngeal mask airway: A prospective study. BMC Anesthesiology 2014, 14:56-58.

14. Ahmed A, Abbasi S, Ghafoor HB, Ishaq M: Postoperative sore throat after elective surgical procedures. J Ayub Med Coll Abbottabad 2007; 19: $12-4$.

15. Borazan et al. Oral magnesium lozenge reduces Postoperative sore throat: A randomized, prospective, placebo-controlled study. Anesthesiology, July 2012. Published ahead of print. Doi: 10 . 1097/ALN.0b013e3182639d5f

16. Lin CY, Tsai PS, Hung YC, Huang CJ. L-type calcium channels are involved in mediating the anti-inflammatory effects of magnesium sulphate. Br J Anaesth. 2010; 104:44-51.

17. Ahuja V, Mitra S, Sarna R. Nebulized ketamine decreases incidence and severity of post-operative sore throat. Indian J Anaesth. 2015; 59:37-42.

18. Blitz M, Blitz S, Hughes R, Diner B, Beasley R, Knopp J, and et al. Aerosolized magnesium sulfate for acute asthma: A systematic review. Chest. 2005; 128:337-44

19. Maurice Blitz, MD; Sandra Blitz, MSc; Rodney Hughes, MBChB; Barry Diner, MD; Richard Beasley, MD; Jennifer Knopp, BScN, MN; Brian H. Rowe, MD, MSc, FCCP . Aerosolized Magnesium Sulfate for Acute Asthma. Chest. 2005; 128(1):337-344. doi:10.1378/chest.128.1.337

20. The science of nebulized drug delivery. O'Callaghan C, Barry PW Thorax. 1997 Apr; 52 Suppl (2):S31-44.

Copyright: (C) the author(s), 2020. It is an open-access article distributed under the terms of the Creative Commons Attribution License (CC BY 4.0), which permits authors to retain ownership of the copyright for their content, and allow anyone to download, reuse, reprint, modify, distribute and/or copy the content as long as the original authors and source are cited.

How to cite this article: Padma T, Raju B, Raviraj GS. The Effect of Nebulized Magnesium Sulphate on The Incidence of Postoperative Sorethroat. Anesthesia. Acad. Anesthesiol. Int. 2020;5(1):185-190.

DOI: dx.doi.org/10.21276/aan.2020.5.1.39

Source of Support: Nil, Conflict of Interest: None declared. 